\title{
Jeongeupia naejangsanensis gen. nov., sp. nov., a cellulose-degrading bacterium isolated from forest soil from Naejang Mountain in Korea
}

Correspondence

Jae Jun Song

jjsong@kribb.re.kr
Jung-Hoon Yoon, ${ }^{1}$ Jong Hyun Choi, ${ }^{2}$ So-Jung Kang, ${ }^{1}$ Nack-Shick Choi, ${ }^{2}$
Jung-Sook Lee ${ }^{1}$ and Jae Jun Song

${ }^{1}$ Korea Research Institute of Bioscience and Biotechnology (KRIBB), PO Box 115, Yusong, Taejon, Republic of Korea

${ }^{2}$ Enzyme Based Fusion Technology Research Team, Jeonbuk Branch Institute, KRIBB, Jeonbuk 580-185, Republic of Korea

A Gram-stain-negative, motile, rod-shaped, cellulose-degrading bacterial strain, BIO-TAS4-2 ${ }^{\top}$, which belongs to the Betaproteobacteria, was isolated from forest soil from Naejang Mountain, Korea, and its taxonomic position was investigated by using a polyphasic study. Strain BIO-TAS4$2^{\top}$ grew optimally at $\mathrm{pH} 7.0-8.0$, at $30{ }^{\circ} \mathrm{C}$ and in the presence of $0-1.0 \%(\mathrm{w} / \mathrm{v}) \mathrm{NaCl}$.

Phylogenetic trees based on 16S rRNA gene sequences showed that strain BIO-TAS4- ${ }^{\top}$ clustered with members of the genera Andreprevotia, Silvimonas and Deefgea of the family Neisseriaceae, with which it exhibited 16S rRNA gene sequence similarities of 93.5-94.2\%. Strain BIO-TAS4- $2^{\top}$ contained Q-8 as the predominant ubiquinone and summed feature 3 $\left(\mathrm{C}_{16: 1} \omega 7 \mathrm{c}\right.$ and/or iso- $\left.\mathrm{C}_{15: 0} 2-\mathrm{OH}\right)$ and $\mathrm{C}_{16: 0}$ as the major fatty acids. The DNA $\mathrm{G}+\mathrm{C}$ content was $63.8 \mathrm{~mol} \%$. Strain BIO-TAS4- $2^{\top}$ could be differentiated from members of phylogenetically related genera by differences in fatty acid composition, DNA G $+\mathrm{C}$ content and some phenotypic properties. On the basis of phenotypic, chemotaxonomic and phylogenetic data, strain BIOTAS4- $2^{\top}$ is considered to represent a novel species in a new genus, for which the name Jeongeupia naejangsanensis gen. nov., sp. nov. is proposed, with BIO-TAS4-2 ${ }^{\top}(=\mathrm{KCTC}$ $22633^{\top}=$ CCUG $57610^{\top}$ ) as the type strain.
During the screening of cellulose-degrading micro-organisms from forest soil collected from Naejang Mountain in Korea, many bacterial strains have been isolated and characterized taxonomically. One of these isolates, BIOTAS4 $-2^{\mathrm{T}}$, which formed a distinct phylogenetic lineage within the Betaproteobacteria, is the subject of this study. The aim of the present work was to determine the taxonomic position of strain BIO-TAS4- $2^{\mathrm{T}}$ by using a polyphasic characterization that included determination of the phenotypic and chemotaxonomic properties, as well as a phylogenetic investigation based on 16S rRNA gene sequences.

Bacterial strains were isolated from a soil sample collected from Naejang Mountain, Korea. The soil sample (1 g) was added to PBS buffer and serially diluted. The diluted suspension was spread onto solid Luria-Bertani (BD) medium, adjusted to initial $\mathrm{pH} 7.0$, containing $0.2 \%(\mathrm{w} / \mathrm{v})$ Azo-CM-cellulose (Megazyme). The culture was incubated at $37{ }^{\circ} \mathrm{C}$ for 3-5 days. Cellulolytic micro-organisms were isolated if clear zones around colonies due to degradation

The GenBank/EMBL/DDBJ accession number for the 16S rRNA gene sequence of strain BIO-TAS4-2 ${ }^{\top}$ is FJ669217. of Azo-CM-cellulose were observed. Of the isolates, strain BIO-TAS4- $2^{\mathrm{T}}$, which showed an excellent ability to form a clear zone, was selected and used for further study. The type strains of three closely related species were used as reference strains for phenotypic characterization and fatty acid analysis: Andreprevotia chitinilytica DSM $18519^{\mathrm{T}}$ and Deefgea rivuli DSM $18356^{\mathrm{T}}$ were obtained from the Deutsche Sammlung von Mikroorganismen und Zellkulturen, Braunschweig, Germany; and Silvimonas terrae KCTC $12358^{\mathrm{T}}$ was obtained from the Korean Collection for Type Cultures, Taejon, Korea. To investigate morphological, physiological and biochemical characteristics, strain BIO-TAS4-2 $2^{\mathrm{T}}$ was cultivated routinely on trypticase soy agar (TSA; Difco) at $30{ }^{\circ} \mathrm{C}$. Cell morphology was examined by light microscopy (Nikon E600) using cells from exponentially growing cultures. The Gram reaction was determined using the bioMérieux Gram stain kit according to the manufacturer's instructions. Growth at various temperatures $(4,10,20,25,28,30,35,37,40,45$, 50 and $55^{\circ} \mathrm{C}$ ) was measured in trypticase soy broth (TSB; Difco). The $\mathrm{pH}$ range for growth was determined in nutrient broth (Difco) adjusted, prior to sterilization, to various $\mathrm{pH}$ values $(\mathrm{pH} 4.5-10.5$ at intervals of 0.5$)$ by 
using sodium acetate/acetic acid or $\mathrm{Na}_{2} \mathrm{CO}_{3}$ buffers. Growth in various $\mathrm{NaCl}$ concentrations $(0,0.5,1.0,2.0$, $3.0,4.0$ and $5.0 \%$, w/v) was investigated using TSB prepared according to the formula of the Difco medium except that $\mathrm{NaCl}$ was excluded. Growth under anaerobic conditions was determined after incubation in an anaerobic chamber on TSA and on TSA supplemented with potassium nitrate $(0.1 \%, \mathrm{w} / \mathrm{v})$, both of which had been prepared anaerobically under a nitrogen atmosphere. Catalase and oxidase activities and hydrolysis of casein, gelatin, hypoxanthine, starch, Tweens $20,40,60$ and 80 , tyrosine, urea and xanthine were determined as described by Cowan \& Steel (1965). Hydrolysis of aesculin and nitrate reduction were examined as described by Lányí (1987). Susceptibility to antibiotics was tested by placing antibiotic-impregnated discs on TSA plates that were seeded with suspensions of the test strain. Antibiotics tested were polymyxin B (100 U), streptomycin $(50 \mu \mathrm{g})$, penicillin $\mathrm{G}(20 \mathrm{U})$, chloramphenicol $(100 \mu \mathrm{g})$, ampicillin $(10 \mu \mathrm{g})$, cephalothin $(30 \mu \mathrm{g})$, gentamicin $(30 \mu \mathrm{g})$, novobiocin $(5 \mu \mathrm{g})$, tetracycline $(30 \mu \mathrm{g})$, kanamycin $(30 \mu \mathrm{g})$, lincomycin $(15 \mu \mathrm{g})$, oleandomycin $(15 \mu \mathrm{g})$, neomycin $(30 \mu \mathrm{g})$ and carbenicillin $(100 \mu \mathrm{g})$. Utilization of various substrates, enzyme activities, and other physiological and biochemical properties were tested by using the API 20E, API 20NE, API $50 \mathrm{CH}$ and API ZYM systems (bioMérieux). Cells were suspended in AUX medium according to the manufacturer's instructions to inoculate the API $50 \mathrm{CH}$ system.

Cell biomass of strain BIO-TAS4-2 ${ }^{\mathrm{T}}$ for DNA extraction and for isoprenoid quinone analysis was obtained from cultures grown in TSB at $30{ }^{\circ} \mathrm{C}$. Chromosomal DNA was isolated and purified according to the method described by Yoon et al. (1996), with the exception that RNase T1 was used in combination with RNase A to minimize contamination with RNA. The 16S rRNA gene was amplified by PCR using two universal primers as described previously (Yoon et al., 1998). Sequencing of the amplified 16S rRNA gene and phylogenetic analysis were performed as described by Yoon et al. (2003). Alignment of sequences was carried out with CLUSTAL W software (Thompson et al., 1994). Gaps at the 5' and 3' ends of the alignment were omitted from further analysis. Phylogenetic trees were inferred by using three tree-making algorithms: the neighbour-joining (Saitou \& Nei, 1987), maximumlikelihood (Felsenstein, 1981) and maximum-parsimony (Kluge \& Farris, 1969) methods implemented within the PHYLIP package (Felsenstein, 1993). Evolutionary distance matrices for the neighbour-joining method were calculated by using the algorithm of Jukes \& Cantor (1969) with the program DNADIST. The stability of relationships was assessed by bootstrap analysis based on 1000 resamplings of the neighbour-joining dataset by using the programs SEQBOOT, DNADIST, NEIGHBOR and CONSENSE of the PHYLIP package. Isoprenoid quinones were extracted according to the method of Komagata \& Suzuki (1987) and analysed using reversed-phase HPLC and a YMC ODS-A
$(250 \times 4.6 \mathrm{~mm})$ column. For cellular fatty acid analysis, cell mass of strain BIO-TAS4-2 ${ }^{\mathrm{T}}$, A. chitinilytica DSM $18519^{\mathrm{T}}$, D. rivuli DSM $18356^{\mathrm{T}}$ and S. terrae KCTC $12358^{\mathrm{T}}$ was harvested from TSA plates after incubation for 3 days at $30{ }^{\circ} \mathrm{C}$. Fatty acids were extracted and fatty acid methyl esters were prepared according to the standard protocol of the MIDI/Hewlett Packard Microbial Identification System (Sasser, 1990). The DNA G $+\mathrm{C}$ content was determined by the method of Tamaoka \& Komagata (1984) with the modification that DNA was hydrolysed and the resultant nucleotides were analysed by reversed-phase HPLC.

Morphological, cultural, physiological and biochemical characteristics of strain BIO-TAS4- $2^{\mathrm{T}}$ are given in the genus and species descriptions (see below) or are shown in Table 1. The almost complete 16S rRNA gene sequence of strain BIO-TAS4- $2^{\mathrm{T}}$ determined in this study comprised $1490 \mathrm{nt}$, representing approximately $96 \%$ of the Escherichia coli 16S rRNA gene sequence. In the phylogenetic tree based on the neighbour-joining algorithm, strain BIO-TAS4- $2^{\mathrm{T}}$ formed a cluster with members of the genera Andreprevotia, Silvimonas and Deefgea, which belong to the family Neisseriaceae (Fig. 1). This topology was also found in trees constructed using the maximum-likelihood and maximum-parsimony algorithms (Fig. 1). Strain BIOTAS4- $2^{\mathrm{T}}$ exhibited 16S rRNA gene sequence similarities of 94.2, 93.5 and $93.6 \%$ to the type strains of A. chitinilytica, S. terrae and D. rivuli, respectively, and of less than $92.2 \%$ to other species used in the phylogenetic analysis.

The predominant isoprenoid quinone detected in strain BIO-TAS4- $2^{\mathrm{T}}$ was ubiquinone-8 (Q-8). The cellular fatty acid profile of strain BIO-TAS4- $2^{\mathrm{T}}$ is shown in Table 2, together with those of members of the genera Andreprevotia, Silvimonas and Deefgea also analysed in this study. Strain BIO-TAS4-2 $2^{\mathrm{T}}$ had large amounts of unsaturated, straight-chain and hydroxy fatty acids; the major components $(>10 \%$ of total fatty acids) were summed feature $3\left(\mathrm{C}_{16: 1} \omega 7 c\right.$ and/or iso- $\left.\mathrm{C}_{15: 0} 2-\mathrm{OH}\right)$ and $\mathrm{C}_{16: 0}$. The DNA $\mathrm{G}+\mathrm{C}$ content of strain BIO-TAS4-2 ${ }^{\mathrm{T}}$ was $63.8 \mathrm{~mol} \%$.

Phylogenetic analyses based on 16S rRNA gene sequences showed that strain BIO-TAS4- $2^{\mathrm{T}}$ does not fall within the radiation encompassed by a recognized genus, but forms an independent evolutionary lineage within the family Neisseriaceae belonging to the Betaproteobacteria (Fig. 1). The 16S rRNA gene sequence similarity values between strain BIO-TAS4 $-2^{\mathrm{T}}$ and other genera were relatively low $(<94.2 \%)$. The predominant ubiquinone type (Q-8) of strain BIO-TAS4- $2^{\mathrm{T}}$ was the same as that of members of the phylogenetically related genera Andreprevotia, Silvimonas and Deefgea (Yang et al., 2005; Stackebrandt et al., 2007; Weon et al., 2007). When cultivated under identical conditions, the fatty acid profile of strain BIOTAS4 $-2^{\mathrm{T}}$ differed from those of the phylogenetically related genera (Table 2). Strain BIO-TAS4-2 ${ }^{\mathrm{T}}$ could be differentiated from members of the genera Andreprevotia and Silvimonas by differences in phenotypic properties, includ- 
Table 1. Differential phenotypic characteristics of Jeongeupia naejangsanensis BIO-TAS4- $2^{\top}$ and some phylogenetically related taxa

Taxa: 1, strain BIO-TAS4-2 ${ }^{\mathrm{T}}$ (Jeongeupia naejangsanensis gen. nov., sp. nov.); 2, A. chitinilytica (data from Weon et al., 2007; and this study); 3, S. terrae (Weon et al., 2007; and this study); 4, D. rivuli (Stackebrandt et al., 2007; and this study). +, Positive reaction; - , negative reaction; $\mathrm{w}$, weakly positive reaction; NG, no growth. All taxa are positive for motility, catalase, oxidase and $N$-acetyl- $\beta$-glucosaminidase activities, and utilization of ribose, fructose and gluconate. All taxa are negative for Gram-staining, utilization of glycerol, erythritol, L-xylose, methyl $\beta$-D-xyloside, sorbose, dulcitol, inositol, sorbitol, methyl $\alpha$-D-mannoside, methyl $\alpha$-D-glucoside, amygdalin, arbutin, lactose, melibiose, inulin, melezitose, raffinose, D-tagatose, D-fucose, 2-ketogluconate, 5-ketogluconate and phenylacetate, and lipase (C14), valine arylamidase, cystine arylamidase, trypsin, $\alpha$-chymotrypsin, $\alpha$-galactosidase, $\beta$-galactosidase, $\beta$-glucuronidase, $\beta$-glucosidase, $\alpha$-mannosidase and $\alpha$-fucosidase activities.

\begin{tabular}{|c|c|c|c|c|}
\hline Characteristic & 1 & 2 & 3 & 4 \\
\hline Anaerobic growth & + & - & + & + \\
\hline Growth at $40{ }^{\circ} \mathrm{C}$ & + & - & + & - \\
\hline Nitrate reduction & + & - & + & + \\
\hline Glucose fermentation & + & + & + & - \\
\hline \multicolumn{5}{|l|}{ Hydrolysis of: } \\
\hline Aesculin & - & $-{ }^{*}$ & $+^{*}$ & $-*$ \\
\hline Casein & - & $-{ }^{*}$ & $-*$ & $+^{*}$ \\
\hline Gelatin & - & + & - & - \\
\hline Starch & - & $+^{*}$ & $+^{*}$ & $-{ }^{\star}$ \\
\hline Tween 80 & - & $+^{*}$ & $+^{*}$ & $\mathrm{NG}^{*}$ \\
\hline \multicolumn{5}{|l|}{ Utilization of:* } \\
\hline D-Arabinose & - & - & + & - \\
\hline L-Arabinose & - & + & + & - \\
\hline D-Xylose & - & + & + & - \\
\hline Adonitol & + & - & - & - \\
\hline Galactose & - & + & + & - \\
\hline Glucose & + & + & - & + \\
\hline Mannose & + & + & + & - \\
\hline Rhamnose & - & + & + & - \\
\hline D-Mannitol & - & + & + & - \\
\hline $\mathrm{N}$-Acetylglucosamine & + & + & + & - \\
\hline Aesculin & - & - & + & - \\
\hline Salicin & - & - & + & - \\
\hline Cellobiose & - & - & + & - \\
\hline Maltose & - & + & + & - \\
\hline Sucrose & - & - & + & + \\
\hline Trehalose & - & - & + & - \\
\hline Starch & - & + & + & - \\
\hline Glycogen & - & + & + & - \\
\hline Xylitol & + & - & - & - \\
\hline Gentiobiose & - & + & + & - \\
\hline Turanose & - & - & + & - \\
\hline D-Lyxose & + & - & + & - \\
\hline L-Fucose & - & - & + & - \\
\hline D-Arabitol & - & + & + & - \\
\hline L-Arabitol & + & - & - & - \\
\hline Adipate & - & - & + & - \\
\hline
\end{tabular}

Table 1. cont.

\begin{tabular}{|lcccc|}
\hline Characteristic & $\mathbf{1}$ & $\mathbf{2}$ & $\mathbf{3}$ & $\mathbf{4}$ \\
\hline Caprate & + & - & - & - \\
Malate & + & + & + & - \\
Citrate & + & - & - & - \\
Enzyme activity (by API ZYM):* & & & & \\
$\quad$ Alkaline phosphatase & - & - & W & - \\
Lipase (C4) & W & - & - & - \\
Esterase lipase (C8) & W & W & W & - \\
Leucine arylamidase & + & W & W & W \\
Acid phosphatase & + & + & + & - \\
Naphthol-AS-BI-phosphohydrolase & - & - & + & w \\
$\alpha-G l u c o s i d a s e$ & - & + & + & - \\
DNA G+C content (mol\%) & 63.8 & 62 & 58 & 49 \\
\hline
\end{tabular}

${ }^{*}$ Data for reference species determined in this study are those of the type strains.

ing anaerobic growth, nitrate reduction, hydrolysis of some substrates and utilization of substrates, as shown in Table 1 , as well as by differences in fatty acid composition, particularly $\mathrm{C}_{18: 1} \omega 7 c$ and cyclo- $\mathrm{C}_{17: 0}$, as shown in Table 2 . Strain BIO-TAS4- $2^{\mathrm{T}}$ also differed from $D$. rivuli in its DNA $\mathrm{G}+\mathrm{C}$ content and by differences in physiological properties (Table 1). Therefore, on the basis of the phylogenetic data and differential chemotaxonomic and phenotypic properties, strain BIO-TAS4- $2^{\mathrm{T}}$ is considered to represent a novel species in a new genus within the Betaproteobacteria, for which the name Jeongeupia naejangsanensis gen. nov., sp. nov. is proposed.

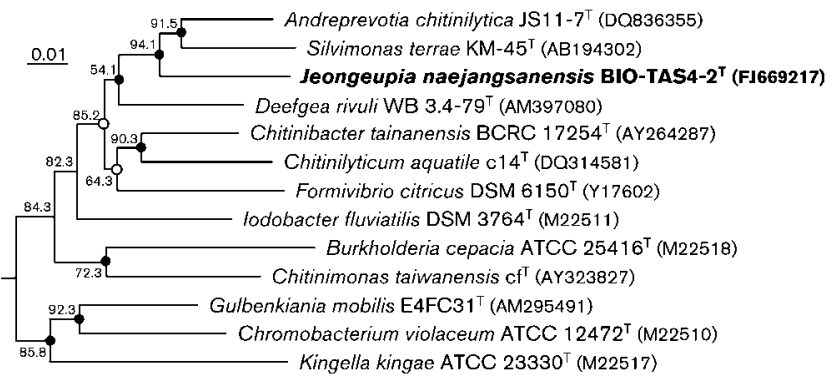

Fig. 1. Neighbour-joining phylogenetic tree based on $16 \mathrm{~S}$ rRNA gene sequences showing the positions of Jeongeupia naejangsanensis BIO-TAS4-2 ${ }^{\top}$ and some other related taxa. Bootstrap values (expressed as percentages of 1000 replications) $>50 \%$ are shown at branch points. Filled circles indicate that the corresponding nodes were also recovered in trees generated with the maximum-likelihood and maximum-parsimony algorithms. Open circles indicate that the corresponding nodes were also recovered in the tree generated with the maximum-likelihood algorithm. E. coli ATCC $11775^{\top}$ was used as an outgroup (not shown). Bar, 0.01 substitutions per nucleotide position. 
Table 2. Cellular fatty acid contents (\%) of Jeongeupia naejangsanensis $\mathrm{BIO}-\mathrm{TAS}-2^{\top}$ and some phylogenetically related strains

Strains: 1, BIO-TAS4- $2^{\mathrm{T}}$ (Jeongeupia naejangsanensis gen. nov., sp. nov.); 2, A. chitinilytica DSM $18519^{\mathrm{T}} ; 3$, S. terrae KCTC $12358^{\mathrm{T}} ; 4$, D. rivuli DSM $18356^{\mathrm{T}}$. All data are from this study. Fatty acids that represent $<0.5 \%$ in all strains were omitted. -, Not detected.

\begin{tabular}{|lcccc|}
\hline Fatty acid & $\mathbf{1}$ & $\mathbf{2}$ & $\mathbf{3}$ & $\mathbf{4}$ \\
\hline Straight-chain & & & & \\
$\mathrm{C}_{12: 0}$ & - & 2.8 & 4.1 & 2.9 \\
$\mathrm{C}_{14: 0}$ & 8.3 & 0.7 & 8.8 & 2.5 \\
$\mathrm{C}_{15: 0}$ & 4.0 & 0.7 & 1.8 & 5.0 \\
$\mathrm{C}_{16: 0}$ & 25.5 & 31.2 & 29.1 & 17.4 \\
$\mathrm{C}_{18: 0}$ & - & 0.6 & 0.1 & 0.2 \\
Unsaturated & & & & \\
$\mathrm{C}_{14: 1} \omega 5 c$ & 0.4 & 0.3 & 1.1 & 0.2 \\
$\mathrm{C}_{15: 1} \omega 6 c$ & 1.2 & 0.6 & 0.5 & 3.8 \\
$\mathrm{C}_{15: 1} \omega 8 c$ & 0.1 & - & 0.1 & 0.6 \\
$\mathrm{C}_{16: 1} \omega 5 c$ & - & 0.4 & 1.0 & 0.3 \\
$\mathrm{C}_{17: 1} \omega 6 c$ & 6.3 & - & - & 0.4 \\
$\mathrm{C}_{17: 1} \omega 8 c$ & - & - & - & 1.1 \\
$\mathrm{C}_{17: 1} \omega 9 c$ & 0.9 & - & - & - \\
$\mathrm{C}_{18: 1} \omega 7 c$ & - & 15.8 & 12.7 & 2.9 \\
Cyclo $_{\mathrm{C}_{17: 0}}$ & & & & \\
$\mathrm{C}_{19: 0} \omega 8 c$ & - & 3.5 & 21.7 & - \\
Hydroxy & - & 0.2 & 1.1 & - \\
$\mathrm{C}_{10: 0} 3-\mathrm{OH}$ & & & & \\
$\mathrm{C}_{12: 0} 3-\mathrm{OH}$ & - & 1.6 & 0.6 & - \\
$\mathrm{C}_{18: 1} 2-\mathrm{OH}$ & 5.3 & 2.4 & 0.1 & 2.4 \\
Summed features* & - & - & 0.7 & - \\
2 & & & & \\
3 & - & - & 4.8 & 0.4 \\
& & 38.2 & 10.8 & 56.6 \\
\hline
\end{tabular}

${ }^{*}$ Summed features represent groups of two or three fatty acids that cannot be separated by GLC with the MIDI system. Summed feature 2 contains $\mathrm{C}_{14: 0} 3-\mathrm{OH}$ and/or iso- $\mathrm{C}_{16: 1}$. Summed feature 3 contains $\mathrm{C}_{16: 1} \omega 7 c$ and/or iso- $\mathrm{C}_{15: 0} 2-\mathrm{OH}$..

\section{Description of Jeongeupia gen. nov.}

Jeongeupia (Je.ong.eup.i'a. N.L. fem. n. Jeongeupia named after Jeongeup, a Korean city, the location of Naejang Mountain).

Cells are Gram-stain-negative and rod-shaped. Facultatively anaerobic. Catalase- and oxidase-positive. The predominant ubiquinone is $\mathrm{Q}-8$. The major fatty acids ( $>10 \%$ of total fatty acids) are summed feature 3 $\left(\mathrm{C}_{16: 1} \omega 7 c\right.$ and/or iso- $\left.\mathrm{C}_{15: 0} 2-\mathrm{OH}\right)$ and $\mathrm{C}_{16: 0}$. The type species is Jeongeupia naejangsanensis.

\section{Description of Jeongeupia naejangsanensis sp. nov.}

Jeongeupia naejangsanensis (nae.jang.san.en'sis. N.L. fem. adj. naejangsanensis pertaining to Naejangsan, the Korean name of Naejang Mountain, from where the type strain was isolated).

Exhibits the following properties in addition to those given in the genus description. Cells are $0.3-0.7 \times 0.7-$ $2.5 \mu \mathrm{m}$. Motile by means of a single polar flagellum. Colonies on TSA are circular to slightly irregular, flat, smooth, glistening, greyish-yellow in colour and 3.0$5.0 \mathrm{~mm}$ in diameter after incubation for 3 days at $30{ }^{\circ} \mathrm{C}$. Optimal temperature for growth is $30^{\circ} \mathrm{C}$. Growth occurs at 10 and $50{ }^{\circ} \mathrm{C}$, but not at 4 or $55{ }^{\circ} \mathrm{C}$. Optimal pH for growth is between 7.0 and 8.0; growth occurs at $\mathrm{pH}$ 5.0, but not at $\mathrm{pH} 4.5$. Growth occurs in the presence of 0 $3.0 \%(\mathrm{w} / \mathrm{v}) \mathrm{NaCl}$, with optimum growth in the presence of $0-1.0 \%(\mathrm{w} / \mathrm{v}) \mathrm{NaCl}$. Anaerobic growth occurs on TSA and on TSA supplemented with nitrate. Cellulose is degraded. Aesculin, casein, gelatin, hypoxanthine, starch, L-tyrosine, urea, xanthine, and Tweens 20, 40, 60 and 80 are not hydrolysed. Nitrate is reduced to nitrite. Indole and $\mathrm{H}_{2} \mathrm{~S}$ are not produced. Glucose is fermented. The following substrates are utilized as carbon and energy sources: $N$-acetylglucosamine, adonitol, L-arabitol, caprate, citrate, fructose, gluconate, glucose, D-lyxose, malate, mannose, ribose and xylitol. The following substrates are not utilized as carbon and energy sources: adipate, aesculin, amygdalin, D-arabinose, L-arabinose, D-arabitol, arbutin, cellobiose, dulcitol, erythritol, D-fucose, L-fucose, galactose, gentiobiose, glycerol, glycogen, inositol, inulin, 2-ketogluconate, 5-ketogluconate, lactose, maltose, Dmannitol, melezitose, melibiose, methyl $\alpha$-D-glucoside, methyl $\alpha$-D-mannoside, methyl $\beta$-D-xyloside, phenylacetate, raffinose, rhamnose, salicin, sorbitol, sorbose, starch, sucrose, D-tagatose, trehalose, turanose, D-xylose and Lxylose. In assays with the API ZYM system: positive for leucine arylamidase, acid phosphatase and $\mathrm{N}$-acetyl- $\beta$ glucosaminidase; weakly positive for esterase (C4) and esterase lipase (C8); and negative for alkaline phosphatase, lipase (C14), valine arylamidase, cystine arylamidase, trypsin, $\alpha$-chymotrypsin, naphthol-AS-BI-phosphohydrolase, $\alpha$-galactosidase, $\beta$-galactosidase, $\beta$-glucuronidase, $\alpha$ glucosidase, $\beta$-glucosidase, $\alpha$-mannosidase and $\alpha$-fucosidase. Susceptible to chloramphenicol, gentamicin, kanamycin, neomycin, polymyxin B, streptomycin and tetracycline, but not to ampicillin, carbenicillin, cephalothin, lincomycin, novobiocin, oleandomycin or penicillin G.

The type strain is BIO-TAS4- $2^{\mathrm{T}}\left(=\mathrm{KCTC} 22633^{\mathrm{T}}=\mathrm{CCUG}\right.$ $57610^{\mathrm{T}}$ ), isolated from soil from Naejang Mountain, Jeongeup city, Korea. The DNA G + C content of the type strain is $63.8 \mathrm{~mol} \%$ (determined by HPLC).

\section{Acknowledgements}

This work was supported by a HTS-based Integrated Technology Development grant (2008-04171) from the Ministry of Education, Science and Technology through the Korea Science and Engineering Foundation and a basic research grant from KRIBB. 


\section{References}

Cowan, S. T. \& Steel, K. J. (1965). Manual for the Identification of Medical Bacteria. London: Cambridge University Press.

Felsenstein, J. (1981). Evolutionary trees from DNA sequences: a maximum likelihood approach. J Mol Evol 17, 368-376.

Felsenstein, J. (1993). PHYLIP (phylogeny inference package) version 3.5. Distributed by the author. Department of Genome Sciences, University of Washington, Seattle, USA.

Jukes, T. H. \& Cantor, C. R. (1969). Evolution of protein molecules. In Mammalian Protein Metabolism, vol. 3, pp. 21-132. Edited by H. N. Munro. New York: Academic Press.

Kluge, A. G. \& Farris, J. S. (1969). Quantitative phyletics and the evolution of anurans. Syst Zool 18, 1-32.

Komagata, K. \& Suzuki, K. (1987). Lipid and cell-wall analysis in bacterial systematics. Methods Microbiol 19, 161-207.

Lányí, B. (1987). Classical and rapid identification methods for medically important bacteria. Methods Microbiol 19, 1-67.

Saitou, N. \& Nei, M. (1987). The neighbor-joining method: a new method for reconstructing phylogenetic trees. Mol Biol Evol 4, 406425.

Sasser, M. (1990). Identification of bacteria by gas chromatography of cellular fatty acids, MIDI Technical Note 101. Newark, DE: MIDI Inc.

Stackebrandt, E., Lang, E., Cousin, S., Päuker, O., Brambilla, E., Kroppenstedt, R. \& Lünsdorf, H. (2007). Deefgea rivuli gen. nov., sp. nov., a member of the class Betaproteobacteria. Int $J$ Syst Evol Microbiol 57, 639-645.

Tamaoka, J. \& Komagata, K. (1984). Determination of DNA base composition by reversed-phase high-performance liquid chromatography. FEMS Microbiol Lett 25, 125-128.

Thompson, J. D., Higgins, D. G. \& Gibson, T. J. (1994). ClustaL W: improving the sensitivity of progressive multiple sequence alignment through sequence weighting, position-specific gap penalties and weight matrix choice. Nucleic Acids Res 22, 4673-4680.

Weon, H.-Y., Kim, B.-Y., Yoo, S.-H., Joa, J.-H., Kwon, S.-W. \& Kim, W.G. (2007). Andreprevotia chitinilytica gen. nov., sp. nov., isolated from forest soil from Halla Mountain, Jeju Island, Korea. Int J Syst Evol Microbiol 57, 1572-1575.

Yang, H.-C., Im, W.-T., An, D.-S., Park, W.-S., Kim, I. S. \& Lee, S.-T. (2005). Silvimonas terrae gen. nov., sp. nov., a novel chitin-degrading facultative anaerobe belonging to the 'Betaproteobacteria'. Int J Syst Evol Microbiol 55, 2329-2332.

Yoon, J.-H., Kim, H., Kim, S.-B., Kim, H.-J., Kim, W. Y., Lee, S. T., Goodfellow, M. \& Park, Y.-H. (1996). Identification of Saccharomonospora strains by the use of genomic DNA fragments and rRNA gene probes. Int J Syst Bacteriol 46, 502-505.

Yoon, J.-H., Lee, S. T. \& Park, Y.-H. (1998). Inter- and intraspecific phylogenetic analysis of the genus Nocardioides and related taxa based on 16S rDNA sequences. Int J Syst Bacteriol 48, 187-194.

Yoon, J.-H., Kang, K. H. \& Park, Y.-H. (2003). Psychrobacter jeotgali sp. nov., isolated from jeotgal, a traditional Korean fermented seafood. Int J Syst Evol Microbiol 53, 449-454. 